\title{
Pengelolaan Dana Kelurahan Dengan Perspektif Community Driven Development di Kelurahan Kladufu Kota Sorong
}

\section{Village Fund Management with Community Driven Development Perspective in Kladufu Village, Sorong City}

\author{
Michel J.N. Potolau1, Safriansyah ${ }^{2}$, Roman H. Saputro ${ }^{3}$ \\ 1,2,3 Jurusan Ilmu Administrasi Fakultas Hukum Ilmu Sosial dan Ilmu Politik Universtias Terbuka
}

Disetujui: Nopember 2021; Direview: Nopember 2021;Diterima: Desember 2021

\begin{abstract}
Abstrak
Tujuan penelitian untuk mengetahui efektifitas pengelolaan dana kelurahan melalui perspektif Community Driven Development. Peneliti menggunakan metode kualitatif dengan teknik analisis triangulasi. Untuk mendapatkan data yang akurat dari informan, maka dilakukan Observasi dan wawancara. Informan dalam penelitian ini adalah perangkat kelurahan yaitu lurah, sekretaris kelurahan, dan perwakilan RT, dengan jumlah informan sebanyak 5 orang yang ditentukan dengan menggunakan teknik purposive sampling. Hasil penelitian menujukan bahwa pengelolaan dana kelurahan masih berfokus pada program fisik dan belum berfokus pada pengembangan pemberdayaan masyarakat. Program yang dilaksanakan masih merupakan program dari pemerintah kota Sorong, Belum seutuhnya berfokus kepada masyarakat, dimana program yang berdampak pada kesejahteraan masyarakat belum dilaksanakan, seperti pengembangan UMKM. Perencanaan dan perancangan dilakukan sepenuhnya oleh perangkat kelurahan. Wewenang kontrol atas sumberdaya terkait pengelolaan dana kelurahan masih sepenuhnya ditangan pemerintah kelurahan sedangkan masyrakat tidak memiliki wewenang kontrol atas sumber daya. Masyarakat dilibatkan hanya sebagai pekerja dalam pelaksanaan program pengeloalan dana kelurahan dan bukan dilibatkan secara luas dalam pengelolaan secara manajemen. Monitoring dan evaluasi dilakukan oleh pemerintah distrik (kecamatan) dan pemerintah kota Sorong.
\end{abstract}

Kata Kunci: Perbandingan, Kinerja, Pembangunan Manusia, Sosial Ekonomi

\begin{abstract}
The purpose of the study was to determine the effectiveness of village fund management through the perspective of Community Driven Development. Researchers used qualitative methods with triangulation analysis techniques. To obtain accurate data from informants, observations and interviews were carried out. The informants in this study were village officials, namely the village head, village secretary, and RT representatives, with a total of 5 informants who were determined using purposive sampling technique. The results of the study indicate that the management of village funds is still focused on physical programs and has not focused on developing community empowerment. The program implemented is still a program from the Sorong city government, not yet fully focused on the community, where programs that have an impact on community welfare have not been implemented, such as the development of MSMEs. Planning and design is carried out entirely by the village apparatus. The control authority over resources related to the management of kelurahan funds is still fully in the hands of the kelurahan government while the community does not have control over resources. The community is involved only as workers in the implementation of the village fund management program and is not widely involved in management. Monitoring and evaluation is carried out by the district (kecamatan) government and the city government of Sorong.
\end{abstract}

Keywords: Management, Community Driven Development

How to Cite : Potolau M.J.N. Safriansyah \& Saputro R.H. (2021). Pengelolaan Dana Kelurahan Dengan Perspektif Community Driven Development di Kelurahan Kladufu Kota Sorong. PUBLIKAUMA: Jurnal Ilmu Administrasi Publik UMA, Vol. 9 (2): 64-70

*Corresponding author:

E-mail: michel@ecampus.ut.ac.id
ISSN 2549-1660 (Print)

ISSN 2580-2011 (Online) 


\section{PENDAHULUAN}

Otonomi daerah dalam Undang-Undang Nomor 32 Tahun 2014 tentang Pemerintahan Daerah disebutkan sebagai hak, wewenang, dan kewajiban daerah otonom untuk mengatur dan mengurus sendiri urusan pemerintahan dan kepentingan masyarakat setempat sesuai dengan peraturan perundangundangan. Otonomi Daerah adalah kewenangan daerah otonom untuk mengatur dan mengurus kepentingan masyarakat setempat menurut prakarsa sendiri berdasarkan aspirasi masyarakat, sesuai dengan peraturan perundang-undangan (Widjaja, 2011). Otonomi daerah ini mencerminkan pelaksanaan demokrasi yang mendorong partisipasi aktif masyarakat dalam pelaksanaan pembangunan daerah serta upaya pemerataan kesejahteraan masyarakat yang berbasis pada pengembangan potensi daerah.

Desentralisasi yang terwujud dalam otonomi daerah, memberikan kewenangan bagi pemerintah daerah untuk dapat mengurus rumah tangganya sendiri dalam menentukan kebijakan, perencanaan, pelaksanaan, penggunaan sumber daya yang ada di masing-masing daerah. Konsep ini dimaksudkan agar kebijakan pembangunan yang selama rezim orde baru di dominasi oleh pemerintah pusat, akan dapat berhasil ketika daerah diberikan ruang untuk melakukan pembangunan pada daerahnya (Hardianto, 2016 dalam Bilote, 2020). Dengan otonomi ini, terbuka kesempatan bagi pemerintah daerah secara langsung membangun kemitraan dengan publik dan pihak swasta daerah yang bersangkutan dalam berbagai bidang. Menurut (Prasetyo, Z. N. D., Pabalik, D., \& Bintari, 2017) Inti dari konsep pelaksanaan otonomi daerah adalah upaya memaksimalkan hasil yang akan dicapai sekaligus menghindari kerumitan dan hal-hal yang menghambat pelaksanaan otonomi daerah. Dengan demikian, tuntutan masyarakat dapat diwujudkan secara nyata dengan penerapan otonomi daerah.

Desa/Kelurahan dalam Undang-Undang Nomor 32 Tahun 2014 ditempatkan sebagai kesatuan masyarakat hukum yang berhak mengatur dan berwenang memgurus kepentingan masyarakat setempat berdasarkan asal-usul dan adat istiadat setempat. Pengertian "mengatur dan mengurus" ini dapat diartikan bahwa Kelurahan memiliki otoritas untuk melaksanakan otonomi yang tentunya diatur dengan peraturan perundang-undangan. Pemahaman kelurahan diatas menempatkan kelurahan sebagai suatu organisasi pemerintahan yang secara politis memiliki kewenangan tertentu untuk mengurus dan mengatur sendiri warga atau kepentingannya, (Londa, 2020).

Kelurahan adalah suatu wilayah yang ditempati oleh sejumlah penduduk yang mempunyai organisasi pemerintahan terendah langsung di bawah camat tetapi tidak memiliki hak untuk menyelenggarakan rumah tangganya sendiri (Kansil, 1988 dalam Assa, C. M., Lapian, M., \& Singkoh, 2020).

Kelurahan Kladufu merupakan salah satu kelurahan yang berada di kota Sorong yang melaksanakan tugas mengatur dan berwenang mengurus kepentingan masyarakat. Sebagai bagian dari perangkat kecamatan dengan fungsi pelaksana pelayanan masyarakat, berdasarkan Permendagri Nomor 130 Tahun 2018 Tentang Kegiatan Pembangunan Sarana dan Prasarana Kelurahan dan Pemberdayaan Masyarakat di Kelurahan, maka kelurahan Kladufu memperoleh dana kelurahan yang bersumber dari Dana Alokasi Umum (DAU), dimana dana kelurahan tersebut dimanfaatkan untuk pembangunan sarana dan prasarana di wilayah kelurahan Kladufu.

Harapan menjadi kelurahan yang berkembang dan maju merupakan tantangan yang dihadapi oleh kelurahan Kladufu kecamatan Sorong Timur kota Sorong dalam kaitannya dengan pengelolaan dana kelurahan. Namun harapan terebut diperhadpkan pada tantangan, dimana keterlibatan masyarakat, baik perencanaan, pelaksanaan, serta kontrol dan evaluasi belum sepenuhnya nampak, karena dalam implikasinya masih didominasi pada pembangunan fisik seperti pembangunan jalan, dimana masyarakat yang menjadi pekerja. Sedangkan pemberdayaan masyakat melalui kegiatan pelatihan, pengembangan UMKM belum terlaksana dan perlu mendapatkan perhatian khusus dari pemerintah setempat. (Chotimah et al., 2019) menyatakan bahwa pemberdayaan masyarakat yaitu merupakan upaya pemerintah untuk mendorong akselerasi 
penurunan angka kemiskinan yang berbasis partisipasi yang diharapkan dapat menciptakan proses penguatan sosial yang dapat mengantar masyarakat miskin menuju masyarakat yang madani, sejahtera, berkeadilan, serta berlandaskan iman dan takwa.

Disisi lain kompetisi global, permasalahan sosial, dan tradisi yang berakar pada masyarakat lokal juga menjadi tantangan tersendiri bagi pemerintah kelurahan Kladufu dalam pengelolaan dana Kelurahan. Pemberdayaan masyarakat mestinya dilakukan sebagai antisipasi terhadap berbagai permasalahan dengan memperhatikan kebutuhan dan kepentingan masyarakat dalam menghadapi persoalan-persoalan tersebut

Pentingnya partisipasi masyarakat dalam membangun komunitas sosial merupakan bagian yang selama ini sering ditinggalkan dan berdampak pada ketidak perdulian masyarakat terhadap perkembangan sosial dan lingkungannya, sehingga masyarakat kurang mampu mengantisipasi perubahan yang terjadi (Sardini, N. H., \& Suswantoro, 2016).

Berdasarkan permasalahan yang ada, maka peneliti tertarik melakukan penelitian dengan mengkaji dari perspektif Community Driven Development (CDD), bagaiamana pengelolaan dana kelurahan dengan perspektif CDD?, dengan tujuan penelitian untuk mengetahui efektifitas pengelolaan dana Kelurahan melalui prspektif CDD.

\section{METODE PENELITIAN}

Penelitian ini menggunakan metode penelitian kualitatif dengan Teknik analisis triangulasi, untuk menganalisis pengelolaan dana kelurahan dalam pemberdayaan masyarakat dengan menggunakan pendekatan Community Driven Development (COD). Pengumpulan data dilakuakn dengan teknik observasi dan wawancara ke informan, dimana informan dalam penelitian ini adalah perangkat kelurahan yaitu lurah, sekretaris kelurahan, dan perwakilan RT, dengan jumlah informan sebanyak 5 orang yang ditentukan dengan menggunakan teknik purposive sampling. Lokasi penelitian dialkukan di Kelurahan
Kladufuu, Kecamatan Sorong Timur, Kota Sorong.

\section{HASIL DAN PEMBAHASAN \\ Community Driven Development}

Perspektif Community Driven Development (CDD) merupakan pendekatan pembangunan yang mengedepankan inisiatif masyarakat untuk memperbaiki kualitas hidupnya sendiri. (Kilby, 2011 dalam Mashuri et al., 2020), menyebutkan bahwa terdapat lima karakteristik sebagai kunci utama pendekatan CDD, yang terdiri dari: (1) Fokus pada masyarakat; (2) Perencanaan dan perancangan partisipatif; (3) Kontrol masyarakat atas sumberdaya; Pelibatan masyarakat dalam pelaksanaan serta (5) Monitoring dan evaluasi berbasis masyarakat.

Pendekatan CDD pada dasarnya dapat digunakan secara luas baik pada masyarakat di wilayah pedesaan maupun masyarakat perkotaan atau urban. Hal tersebut ditegaskan oleh (Kilby, 2011 dalam Mashuri et al., 2020) dimana pendekatan CDD dapat digunakan dalam konteks: (1) Infrastruktur masyarakat desa/ kota, jalan desa, listrik desa, irigasi, sumber air, infrastruktur permukiman perkotaan, pendidikan kesehatan; (2) Pengelolaan sumberdaya milik bersama kehutanan, sumberdaya pesisir, sumber air; (3) Pembangunan usaha mikro/ koperasi; (4) Pemerintah daerah/dukungan desentralisasi; dan (5) Pelayanan/barang publik lain yang berskala kecil, tidak kompleks dan membutuhkan kerjasama lokal

Fokus Pada Masyarakat

Permendagri Nomor 130 Tahun 2018 Tentang Kegiatan Pembangunan Sarana dan Prasarana Kelurahan dan Pemberdayaan Masyarakat di Kelurahan merupakan acuan dari pengelolaan dana kelurahan. Pemerintah kelurahan Kladufu yang merupakan penerima mandat dalam 
mengelola dana kelurhan mewujudnyatakan hal tersebut melalui pemanfaatan dana kelurahan. Seuai pernyataan lurah kelurahan Kladufu bahwa dana kelurahan pada semester pertama tahun 2021 Rp. 150.000.000 dialokasikan seluruhnya pada pembangunan infrastruktur yaitu pengecoran jalan. Hali ini sejalan dengan pernyataan sekretaris kelurahan Kladufu dimana Tujuan dari pembangunan jalan ini adalah untuk mempermudah akses transportasi bagi masyarakat, memberikan kenyamanan kepada masyarakat sebagai pengguna jalan.

Implementasi pengelolaan dana kelurahaan yang dilakukan oleh pemerintah kelurahan Kladufu sudah memberi dampak bagi masyarakat, dimana masyarakat bisa menikmati infrastruktur jalan yang baik, namun secara signifikan dampak bagi kesejahteraan masyarakat dari pemanfaatan dana kelurahan ini belum terlihat. (Aida, A. N., \& Zahara, 2018) menyatakan bahwa, "Rencana dari pemanfaatan dana kelurahan ini adalah untuk dana infrastruktur kelurahan, peningkatan kualitas hidup masyarakat kelurahan dan stimulasi perekonomian masyarakat". Untuk itu perlu adanya kegiatan pengembangan ekonomi kemasyarakatan termasuk memberikan pelatihan terkait mambangun dan mengembangakan usaha berbasis kemasyrakatan, hal ini sejalan dengan pernyataan dari (Suwarno, S., \& Bramantyo, 2019), melalui renungan, pemikiran, ide dan gagasan serta pengembangan ketrampilan sebagian masyarakat dalam suatu wilayah yang dapat mengelola wilayahnya menjadi lahan bisnis dan menghasilkan uang, membuat wilayah tersebut mengalami peningkatan kesejahteraan.

\section{Perencanaan dan Perancangan Partisipatif}

Menurut (Adisasmita, 2011 dalam Wahongan, 2019) mengemukakan bahwa, "Pengelolaan bukan hanya melaksanakan suatu kegiatan, akan tetapi merupakan rangkaian kegiatan yang meliputi fungsifungsi manajemen, seperti perencanaan, pelaksanaan, dan pengawasan untuk mencapai tujuan secara efektif dan efisien. Program yang baik tentu harus diawali dengan perencanaan dan perancangan yang melibatkan partisipasi dari pihakpihak yang berkepentingan dalam pengimplementasian program tersebut. Demikian halnya dengan program dalam pengelolaan dana kelurahan, tentunya butuh perencanaan dan perancangan yang baik, sehingga program yang dilaksanakan memberi manfaat bagi masyraakat.

Dilingkup pemerintah kelurahan Kladufu sendiri juga memiliki program yang dalam perencanaan dan perancangannya melibatkan partisipasi dari seluruh perangkat kelurahan, seperti yang dinyatakan oleh beberapa pengurus rukun tetangga (RT) bahwa perencanaan dan perancangan berbagai kegiatan di kelurahan Kladufu melibatkan perangkat kelurahan melalui rapat bersama dengan pimpinan kelurahan, kemudian hasil keputusan rapat dibawa dalam pembahasan di Musrembang. Namun tidak melibatkan masyarakat secara langsung berpartisipasi dalam prose perencanaan dan perancangan program tersebut, hal ini diakibatkan karena di kelurahan Kladufu tidak memiliki lembaga perwakilan masyarakat (LPM) sebagai suatu lembaga yang mewakili aspirasi masyarkat. 
Dalam hal pengelolaan dana kelurahan sistem perencanaan dan perancangan berbagai kegiatan seharusnya bersifat partisipatif yang melibatkan masyarakat secara langsung, hal ini sejalan dengan pernyataan dari (Kilby, (2011) dalam Mashuri et al., 2020) bahwa, "Perancangan sub-proyek tingkat masyarakat dilakukan melalui perencanaan partisipatif". Demikian halnya dengan pernyataan dari (Sardini, N. H., \& Suswantoro, 2016) bahwa Salah satu prinsip yang dapat menstimulasi kemandirian masyarakat adalah program partisipatif, direncanakan, dilaksanakan, diawasi, dan dievaluasi oleh masyarakat.

\section{Kontrol Masyarakat atas Sumberdaya}

Kontrol atas sumberdaya dalam pengelolaan dana kelurahan sepenuhnya dimiliki oleh pemerintah kelurahan. Hal ini sesuai dengan pernyataan dari lurah, sekretaris kelurahan dan perwakilan RT yaitu kontrol terhadap sumberdaya pengelolaan dana kelurahan merupakan kewenangan dari pemerintah kelurahan kladufu, kontrol dari masyarakat atas sumber daya yang ada, diwakili oleh pengurus RT.

Implementasi dari pengelolaan dana kelurahan adalah pelaksanaan berbagai kegiatan yang melibatkan peranserta masyarakat, termasuk didalamnya peran terhadap kontrol atas sumberdaya, (Kilby, (2011) dalam Mashuri et al., 2020) bahwa, "Setidaknya harus ada beberapa bentuk transfer sumberdaya ke masyarakat/ Community Based Organization (CBO), meskipun tingkat kontrol oleh masyarakat dapat bervariasi". Dengan adanya keterlibatan masyaraakt secara langsung terhadap kontrol atas sumberdaya terkait kegiatan pengelolaan dana kelurahan, maka akan mewujudkan akuntabilitas dalam pengelolaan dana kelurahan.

\section{Pelibatan Pelaksanaan Masyarakat dalam} Program yang dilaksanakan oleh pemerintah kelurahan Kladufu dalam pengelolaan dana kelurahan melibatkan masyarakat. Seperti pernyataan lurah dan sekretaris kelurahan bahawa alokasi dana kelurahan semuanya diperuntukan untuk pembangunan jalan yang ada di lingkungan kelurahan Kladufu, dan masyarakat dilibatkan sebagai pekerja.

Masyarakat seharusnya diberi peran lebih luas lagi dalam pelaksanaan pengelolaan dana kelurahan, seperti berperan dalam pengelolaan manajemen dan pengawasan kegiatan. Hal ini sejalan dengan apa yang dikemukakan (Kilby, (2011) dalam Mashuri et al., 2020) bahwa, "Keterlibatan ini sering berbentuk pasokan input, tenaga kerja atau dana secara langsung (sebagai bagian dari "kontribusi masarakat".

Ketika masyarakat dilibatkan secara penuh dalam pelaksanaan pengelolaan dana kelurahan, masyarakat bukan hanya mengetahui manajemen pengelolaan, tetapi masyarakat dapat merasakan dampak dari perubahan yang terjadi dari setiap kegiatan yang dilaksanakan (Gita F. M, 2021).

\section{Monitoring dan Evaluasi Berbasis Masyarakat}

Menurut (Prasetyo, Z. N. D., Pabalik, D., \& Bintari, 2017) secara umum prinsipprinsip pengelolaan Alokasi Dana Kelurahan mengikuti prinsip-prinsip Good Governance, di antaranya: transparansi, akuntabilitas, partisipatif, dan kesetaraan. Mewujudkan terciptanya good govermance salah satu yang perlu dilakukan adalah pelaksanaan monitoring dan evaluasi. Hal ini juga berlaku bagi pemerintah kelurahan Kladufu terkait penggunaan pengelolaan dana kelurahan.

Berdasarkan hasil wawancara dengan lurah kelurahan Kladufu bahwa bentuk pertanggungjawaban dari penggunaan dana kelurahan yaitu pemerintah kelurahan Kladufu memberikan laporan hasil penggunaan dana ke distrik (kecamatan) untuk 
diperiksa, selanjutnya laporan tersebut di teruskan ke tingkat pemerintah kota sorong.

Evaluasi juga dilakukan oleh pihak inspektorat sebagai auditor yang mendapatkan mandat untuk melakukan audit terkait penggunaan dana kalurahan. Pada dasaranya pelaksanaan evaluasi telah diterapkan terkait penggunaan dana kelurahan tersebut, namun belum berbasis masyarakat, masyarakat belum terlibat dalam pelaksanaan monitoring dan evaluasi secara formal. Masyarakat perlu memiliki peran untuk melakukan monitoring dan evaluasi untuk pengendalian kualitas. Pengendalian kualitas menurut (Mujiarto, M., Susanto, D., \& Bramantyo, 2019) adalah keseluruhan cara yang digunakan untuk menentukan dan mencapai standar mutu

Keterlibatan masyarakat dalam kegiatan monitoring dan evaluasi pengelolaan dana kelurahan akan mewujudkan suatu transparansi dalam pengelolaan dana kelurahan. Transparansi akan mengurangi tingkat ketidak pastian dalam proses pengambilan keputusan mengenai pengelolaan dana kelurahan Selain itu, transparansi juga dapat mempersempit peluang untuk korupsi dalam lingkup pemerintah kelurahan dengan masyarakat ikut berpartisipasi dalam pengambilan keputusan (Kasenda, H., Sambiran, S., \& Sumampow, 2021).

\section{SIMPULAN}

Program pengelolaan dana kelurahan masih berfokus pada program fisik dan belum berfokus pada pengembangan pemberdayaan masyarakat seperti pengembangan UMKM. Perencanaan dan perancangan dilakukan sepenuhnya oleh perangkat kelurahan dan belum melibatkan masyarakat. Wewenang kontrol atas sumberdaya terkait pengelolaan dana kelurahan masih sepenuhnya ditangan pemerintah kelurahan sedangkan masyarakat tidak memiliki wewenang kontrol atas sumber daya. Masyarakat dilibatkan hanya sebagai pekerja dalam pelaksanaan program pengelolaan dana kelurahan dan bukan dilibatkan secara luas dalam pengelolaan secara manajemen. Monitoring dan evaluasi dilakukan oleh pemerintah distrik (kecamatan) dan pemerintah kota Sorong, monitoring dan belum melibatkan masyarakat

\section{DAFTAR PUSTAKA}

Aida, A. N., \& Zahara, E. L. (2018). Dana Kelurahan dan Tantangannya. Pusat Kajian Anggaran Badan Keahlian DPR RI.

Assa, C. M., Lapian, M., \& Singkoh, F. (2020). Issn : 2337 - 5736. 2(5), 1-12.

Bilote, D. N. (2020). Efektivitas Lembaga Pemberdayaan Masyarakat Dalam Pengelolaan Dana Kelurahan Di Kecamatan Lembeh Utara Kota Bitung. Publikauma: Jurnal Administrasi Publik, 8(2), 96-102.

Chotimah, C., Widodo, R., \& Handayani, T. (2019). Efektivitas Lembaga Pemberdayaan Masyarakat Desa Dalam Pelaksanaan Pembangunan Desa Bululawang. Jurnal Civic Hukum, 4(2), 103. https://doi.org/10.22219/jch.v4i2.9184

Gita F. M. (2021). IMPLEMENTASI KEBIJAKAN PEMANFAATAN DANA KELURAHAN DALAM PENINGKATAN PELAYANAN PUBLIK DI KELURAHAN PAGENTAN KECAMATAN SINGOSARI KABUPATEN MALANG PROVINSI JAWA TIMUR. IPDN Jatinagor.

Kasenda, H., Sambiran, S., \& Sumampow, I. (2021). Transparansi Pengelolaan Dana Kelurahan Dalam Pembangunan Di Kelurahan Ranomea Kecamatan Amurang Timur Kabupaten Minahasa Selatan. GOVERNANCE, 1(2).

Londa, V. Y. (2020). Efektivitas Pengelolaan Dana Kelurahan Dalam Rangka Peningkatan Sarana Dan Prasarana Dan Pemberdayaan Masyarakat Di Kelurahan Bahu Kecamatan Malalayang Kota Manado. Jurnal Administrasi Publik, 6(95), 61-73.

Mashuri, M., Suwarno, S., \& Pramono, T. (2020). Pengelolaan Dana Kelurahan Dalam Perspektif Community Driven Development. Jurnal Mediasosian: Jurnal Ilmu Sosial Dan Administrasi Negara, 4(1), 51-62. https://doi.org/10.30737/mediasosian.v4i1. 819

Mujiarto, M., Susanto, D., \& Bramantyo, R. Y. (2019). Strategi Pelayanan Kesehatan Untuk Kepuasan Pasien Di UPT Puskesmas Pandean Kecamatan Dongko Kabupaten Trenggalek. Jurnal Ilmu Sosial Dan Administrasi Negara, 3(1).

Prasetyo, Z. N. D., Pabalik, D., \& Bintari, W. C. (2017). Implementasi Alokasi Dana 
Michel J.N. Potolau, dkk, Pengelolaan Dana Kelurahan Dengan Perspektif Community Driven Development

Kelurahan Dalam Pemberdayaan Masyarakat di Kelurahan Malawele Kabupaten Sorong. Gradual, 6(2), 42-53.

Sardini, N. H., \& Suswantoro, G. (2016). 60 Tahun Jimly Asshiddiqie: Menurut Para Sahabat (1st ed.). Yayasan Pustaka Obor Indonesia.

Suwarno, S., \& Bramantyo, R. Y. (2019). Pengaruh Gaya Kepemimpinan Terhadap Kinerja Karyawan. Majalah Ilmiah UNIKOM, 16(2), 185-188.

https://doi.org/10.34010/miu.v16i2.1361

Wahongan, S. (2019). Partisipasi Masyarakat Dalam Pengelolaan Dana Kelurahan Bagi Pembangunan. Jurnal Politico, 8(1), 1-10.

Widjaja, H. A. W. (2011). Otonomi Daerah dan Daerah Otonom. Raja Grafindo Persada. 